\title{
Analisis Kemampuan Number Sense Dalam Pemecahan Masalah Matematika
}

\author{
Yandika Nugraha ${ }^{1}$, Mulhamah ${ }^{2}$ \\ ${ }^{1}$ Tadris Matematika, Universitas Islam Negeri Mataram, yandika310189@yahoo.com \\ ${ }^{2}$ Pendidikan Guru Madrasah Ibtidaiyah, Universitas Islam Negeri Mataram, mulhamah.pmat@gmail.com
}

\section{INFO ARTIKEL}

Riwayat Artikel:

Diterima: 12-09-2017

Disetujui: 25-10-2017

\section{Kata Kunci:}

Number sense

Pemecahan masalah

Mahasiswa

\begin{abstract}
ABSTRAK
Abstrak: Penelitian ini bertujuan untuk mendeskripsikan kemampuan number sense mahasiswa Program Studi PGMI FTK UIN Mataram. Penelitian ini merupakan penelitian kualitatif. Subjek penelitian adalah mahasiswa PGMI konsentrasi matematika. Prosedur pemilihan subjek menggunakan purposive sampling. Pengumpulan data dilakukan dengan cara think aloud method. Teknik analisis data dilakukan dengan cara: (1) mengelompokkan subjek berdasarkan kemampuan awal matematika tinggi, sedang, dan rendah: , (2) menyajikan data, dan (3) menyimpulkan kemampuan number sense. Hasil penelitian menunjukkan bahwa mahasiswa pada kemampuan awal tinggi sudah menguasai konsep dasar dari number sense. Pada kemampuan awal sedang dan rendah belum memahami dan menguasai sepenuhnya konsep dasar number sense.
\end{abstract}

\begin{abstract}
The purpose of this research was to describe the number sense ability of student at Study Program of PGMI FTK UIN Mataram. This research was a qualitative research. The subject were the students of mathematics concentration. Subject selection procedure was done by purposive sampling method. Techniques of data analysis were done by: (1) classifying subjects based on high, medium, and low mathematics ability. (2) presenting the data, and (3) summarizing the number sense capabilities. Based on the research, students in the high mathematic ability have mastered the basic concept of the number sense. The student at middle and low mathematics ability have not been able to fully understand and master the basic concept of number sense.
\end{abstract}

\section{A. LATAR BELAKANG}

Pengenalan konsep bilangan merupakan awal pembelajaran matematika di tingkat pendidikan dasar (sekolah dasar maupun madrasah ibtidaiyah). Guru tidak banyak menemukan kesulitan saat membahas bentuk bilangan dikarenakan guru mampu menerjemahkan objek kehidupan sehari-hari kedalam bentuk matematika, seperti lambang 1 yang diajarkan dengan memegang 1 buah pulpen, dan berbagai hal lainnya. Akan tetapi, disaat pembahasan lebih lanjut yang berkaitan dengan pemecahan masalah matematika, terutama berkaitan dengan manipulasi serta perhitungan menggunakan bilangan, sebagian besar guru selalu mengajarkan dan menggunakan cara prosedural. Contoh paling sederhana yang sering dijumpai adalah ketika penggunaan hitung susun dalam menyelesaikan operasi penjumlahan dan pengurangan. Hal ini akan berakibat fatal dimana saat siswa lupa atau bahkan tidak tahu cara prosedural yang biasa diajarkan sehingga akan membuat siswa bingung dan tidak tahu proses selanjutnya. Bahkan siswa terkadang tidak mengetahui maksud dari suatu perhitungan, hanya semata-mata mengaplikasikan suatu rumus. Hal ini mengindikasikan bahwa matematika bukanlah tentang hafalan, teori-teori, maupun rumus-rumus, melainkan ada suatu konsep yang didalamnya terkandung suatu makna.

Ketika anak mengalami kesulitan dalam memecahkan masalah matematika, secara tidak langsung akan mulai tertanam dalam diri siswa bahwa matematika itu sulit hingga menakutkan. Menakutkan bukan karena sulit, tetapi menakutkan karena tidak tahu langkah apa selanjutnya yang harus dikerjakan atau bahkan sama sekali tidak tahu apa maksud dan tujuan dari operasi tersebut. Jika pada tingkat pendidikan dasar (sekolah dasar atau madrasah ibtidaiyah) sudah mengalami hal tersebut, 
dikhawatirkan hal itu akan terus berkelanjutan sampai ke jenjang pendidikan selanjutnya.

Oleh karena itu, untuk menghindari hal tersebut, sedari awal siswa harus mulai ditanamkan konsep bilangan secara berkesinambungan dari awal pengenalan bilangan hingga aplikasi dari bilangan, karena tidak bisa dipungkiri bahwa hampir seluruh konsep matematika dari jenjang pendidikan dasar sampai tinggi selalu melibatkan bilangan. Pembelajaran pemahaman konsep bilangan secara berkesinambungan akan menjadikan siswa tidak lagi melihat matematika sebagai suatu masalah yang sulit, tetapi menjadi tantangan yang mudah dihadapi. Untuk itu, perlu diajarkan suatu kepekaan terhadap bilangan (number sense) dimana peserta didik yang mempunyai number sense yang baik maka secara tidak langsung memiliki sifat luwes, percaya diri, dan mampu mengatasi berbagai macam pertanyaan yang berkaitan dengan bilangan (Fosnote: 2001). ${ }^{1}$ Number Sense membantu siswa berpikir fleksibel dan kreatif dalam menyelesaikan masalah-masalah terkait dengan perhitungan. Menurut Carlyle (2012), dengan number sense dapat meningkatkan kepercayaan diri siswa mengenai bilangan dan operasinya. ${ }^{1}$

Terdapat beberapa alasan sehingga number sense diperlukan dalam pembelajaran matematika di sekolah. Pertama, number sense akan meningkatkan berpikir kreatif serta analitis peserta didik dalam melihat bilangan yang sebelumnya hanya diajarkan prosedur perhitungan berdasarkan hafalan semata. Hal ini sesuai dengan tujuan pembelajaran matematika menurut Depdiknas (2004) yaitu melatih cara berpikir secara sistematis, logis, kritis, kreatif, dan konsisten. ${ }^{3}$ Contoh ketika peserta didik dihadapkan pada permasalahan matematika seperti ketika diberikan pertanyaan $47+47$, maka prosedur penjumlahan pinjam meminjam akan dilakukan. Tetapi jika peserta didik dapat berpikir kreatif, logis, dan analitis, maka $47+47$ dapat dihitung cukup dengan $40+40+14$ atau $50+44$. Penggunaan prosedural simpan meminjam ini juga berlanjut pada operasi perkalian dan pembagian. Ketika menghadapi soal 12 x 101 yang mestinya bisa diselesaikan dengan cara menghitung 12 x 100 lalu hasilnya ditambah dengan 12 . Tetapi, penggunaan simpan pinjam dalam perkalian dan pembagianlah yang sering digunakan oleh peserta didik dalam menyelesaikan soal tersebut. Pada permasalahan pecahan misalnya, adakah nilai antara 2/5 dengan $4 / 5$ ? Peserta didik dalam mengerjakan permasalahan ini jikatidak memiliki pemahaman terhadap bilangan yang kuat, bisa saja mengatakan hanya satu yaitu $3 / 5$. Padahal jika kita ubah dengan dikalikan dengan bilangan $5 / 5$, maka $2 / 5$ menjadi $10 / 25$ dan $4 / 5$ menjadi $20 / 25$ sehingga akan banyak bilangan yang ada antara $2 / 5$ dan $4 / 5$. Pada kasus yang lain, pemahaman konsep pecahan juga dirasa sangat penting, misalnya ketika harus mengurutkan bilangan dari terkecil ke terbesar dari 0,95, 2/4, 61\%, $0,3,30,5$, diperlukan kepekaan terhadap bilangan terutama pecahan dalam menyelesaikan masalah tersebut tanpa harus menghabiskan waktu yang lama.

Alasan yang kedua yaitu, peserta didik harus diajarkan kemampuan berpikir matematis selain kemampuan berhitung cepat dan tepat dikarenakan dengan kecanggihan teknologi seperti adanya kalkulator maupun komputer dapat mengatasi kesulitan berhitung cepat dan tepat. Oleh karena itu, diperlukan keterampilan yang tidak bisa dilakukan oleh kalkulator maupun komputer seperti menganalisa suatu permasalahan menggunakan berbagai macam strategi untuk menemukan solusi.

Menurut NCTM (2000), salah satu yang penting dalam membelajarkan matematika pada tingkat pendidikan dasar adalah mengembangkan kepekaan bilangan. ${ }^{6}$ Hal ini karena pembelajaran matematika tidak hanya ditekankan pada penguasaan proses menghitung, tetapi juga perlu ditanamkan pemaknaan proses perhitungan. Dibutuhkan kecakapan dan kemampuan guru dalam mengajarkan number sense kepada peserta didik dengan baik dan benar. Kemampuan number sense seorang guru tidak akan datang secara tiba-tiba, karena diperlukan waktu dan proses yang tidak sedikit untuk mempelajarinya. Oleh karena itu, peneliti ingin mengetahui sampai sejauh mana kemampuan number sense mahasiswa Program Studi PGMI FITK IAIN Mataram dalam memecahkan masalah matematika terutama pada pecahan, sehingga kedepannya dapat dijadikan pertimbangan dalam pengembangan pembelajaran matematika terkait number sense selama perkuliahan.

\section{B. METODE PENELITIAN}

Penelitian ini menggunakan berjenis penelitian deskriptif dengan pendekatan kualitatif yang dilaksanakan Program Studi Pendidikan Guru Madrasah Ibtidaiyah FTK UIN Mataram. Subjek penelitian ini adalah mahamahasiswa semester 6 yang sedang mengambil konsentrasi matematika. 
Teknik pemilihan subjek dalam penelitian menggunakan metode purposive sampling. Proses pemilihan subjek dilakukan dengan cara menetapkan kriteria pemilihan subjek yaitu subjek berada di kelas penjurusan Matematika semester 6, dapat mengemukakan pendapat baik tulisan atau lisan secara jelas, dan mempunyai kemampuan awal matematika tinggi, sedang, dan rendah. Berdasarkan hasil pertimbangan dari dosen yang mengajar di semester 6 tentang kemampuan mahasiswa dalam mengemukakan pendapat baik secara tertulis maupun lisan, serta kemampuan awal mahasiswa dalam belajar matematika selanjutnya dipilih mahasiswa yang memenuhi kriteria subjek penelitian. Sumber data dalam penelitian yang akan dilaksanakan berupa peristiwa dan subjek penelitian. Peristiwa meliputi kegiatan tanya jawab kepada mahasiswa, sedangkan subjek penelitian, yaitu objek yang akan diteliti untuk mendapatkan data yang diperlukan. Sebelum mengumpulkan data, terlebih dahulu akan ditentukan subjek penelitiannya seperti yang telah dijelaskan pada bagian sebelumnya. Subjek dalam penelitian ini yaitu

TABEL 1

SUBJEK PENELITIAN

\begin{tabular}{llccc}
\hline No & $\begin{array}{c}\text { Kemampuan } \\
\text { Awal }\end{array}$ & Inisial & L/P & Nilai \\
\hline 1 & Tinggi 1 (T1) & M A & L & 95 \\
2 & Tinggi 2 (T2) & W H & L & 95 \\
3 & Sedang 1 (S1) & HI & P & 65 \\
4 & Sedang 2 (S2) & M Az & L & 45 \\
5 & Rendah 1 (R1) & W A F & P & 30 \\
6 & Rendah 2 (R2) & I S & P & 30 \\
\hline
\end{tabular}

Pada penelitian ini, data dikumpulkan langsung oleh peneliti, sehingga instrumen utama penelitian ini peneliti sendiri sebagai pewawancara yang dibantu dengan instrumen bantu berupa soal tes pemecahan masalah pecahan. Instrumen bantu yang digunakan yaitu lembar tes pemecahan masalah yang telah divalidasi oleh 3 validator yang ahli dibidangnya. Instrumen ini terdiri dari 7 soal pada tes yang pertama dan kedua.

Setelah subjek sudah ditentukan, maka peneliti akan mengumpulkan data dengan menggunakan think aloud method, yaitu mahasiswa diminta untuk mengungkapkan ekpresi verbal tentang ide yang dipikirkan ketika menyelesaikan soal kemampuan number sense yang berjumlah 7 soal. Dengan demikian, data yang didapatkan berupa kata-kata tertulis dan kata-kata lisan.
Think aloud method dilakukan seperti langkahlangkah berikut ini: (1) peneliti memberikan soal kepada mahasiswa mengenai masalah number sense, (2) mahasiswa diminta untuk mengerjakan soal yang diikuti dengan ungkapan verbal tentang jawaban tersebut, (3) selama mahasiswa menyelesaikan soal yang diberikan, peneliti memberikan beberapa pertanyaan terkait jawaban yang diberikan mahasiswa. Sebisa mungkin, peneliti akan menggunakan pertanyaan yang sederhana yang mudah dipahami mahasiswa tetapi tidak menghilangkan inti permasalahan.

Dalam penelitian ini, untuk menemukan data yang valid, akan menggunakan triangulasi waktu dengan langkah-langkah sebagai berikut.

a. Peneliti akan mengambil data number sense dengan menggunakan think aloud method sebanyak dua kali dalam waktu yang berbeda.

b. Melakukan pengambilan data pertama.

b. Menganalisis hasil think aloud pada pengambilan data pertama.

c. Melakukan pengambilan data kedua.

d. Menganalisis hasil think aloud pada pengambilan data kedua.

e. Membandingkan hasil pengambilan data pertama dengan hasil pengambilan data kedua.

f. Apabila data hasil pertama dan kedua konsisten, maka data tersebut dinyatakan valid. Dalam hal ini, yang dimaksud dengan konsisten yaitu pengumpulan data pertama dan data kedua memberikan hasil yang identik atau sama.

Tahap analisis data dilakukan setelah penggalian data yang diperoleh dianggap cukup untuk memenuhi maksud dan tujuan penelitian. Setelah data yang dianggap relevan dengan masalah yang diteliti, data selanjutnya dianalisis kembali secara lebih mendalam untuk ditarik kesimpulan yang mudah dipahami oleh diri sendiri dan orang lain.

Metode analisis yang digunakan adalah analisis data kualitatif. Dalam penelitian kualitatif, analisis data dilakukan sejak awal dan sepanjang proses penelitian berlangsung. Proses analisis data pada penelitian ini dilakukan dengan membandingkan hasil dari data think a loud yang pertama dan kedua yang konsisten, kemudian membandingkan dengan kajian teori.

\section{HASIL DAN PEMBAHASAN}

\section{Hasil Penelitian}

Berdasarkan hasil analisis data yang telah dilakukan, didapatkan kemampuan number sense mahasiswa yaitu: 
TABEL 2

HASIL PENELITIAN

\begin{tabular}{|c|c|c|c|c|c|c|c|c|}
\hline \multirow{3}{*}{ 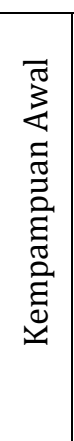 } & & \multirow{2}{*}{\multicolumn{4}{|c|}{ 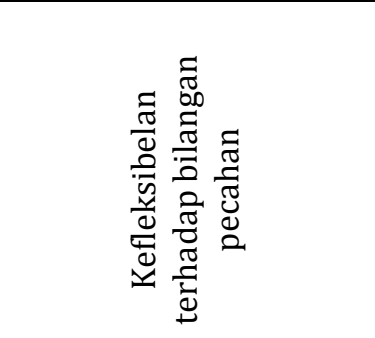 }} & \multirow{2}{*}{\multicolumn{2}{|c|}{ 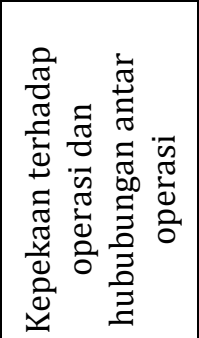 }} & \multirow{3}{*}{ 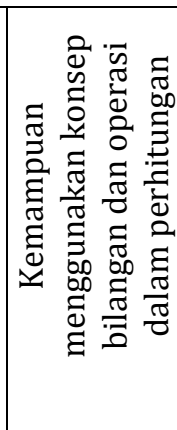 } \\
\hline & : & & & & & & & \\
\hline & & 1 & 2 & 3 & 4 & 5 & 6 & \\
\hline 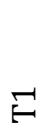 & $\stackrel{\mathbb{\Sigma}}{\mathbb{2}}$ & 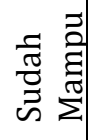 & 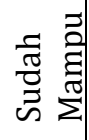 & 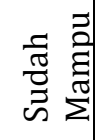 & 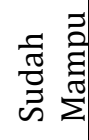 & 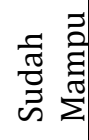 & 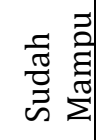 & 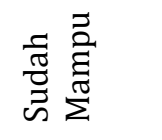 \\
\hline$\stackrel{\simeq}{\tilde{E}}$ & $\begin{array}{l}\frac{1}{3} \\
\end{array}$ & 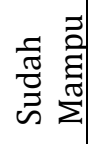 & 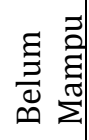 & 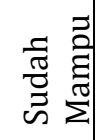 & 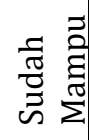 & 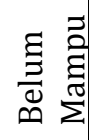 & 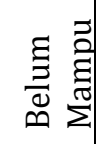 & 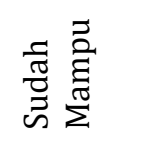 \\
\hline 5 & $\bar{I}$ & 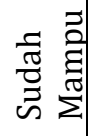 & 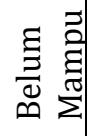 & 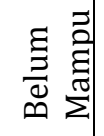 & 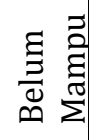 & 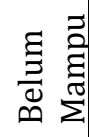 & 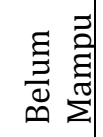 & 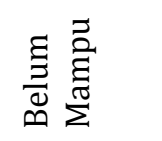 \\
\hline$\approx$ & $\sum_{\Sigma}^{N}$ & 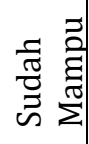 & 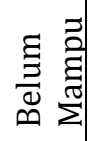 & 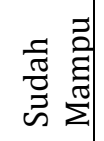 & 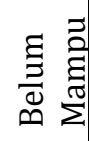 & 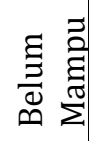 & 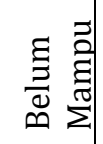 & 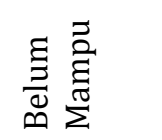 \\
\hline צ' & $\begin{array}{l}\frac{1}{4} \\
3\end{array}$ & 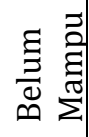 & 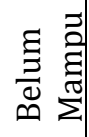 & 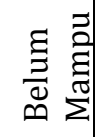 & 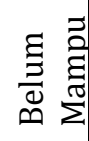 & 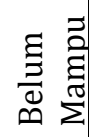 & 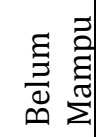 & 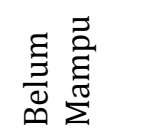 \\
\hline & 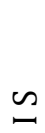 & 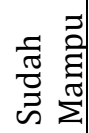 & 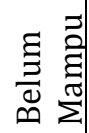 & 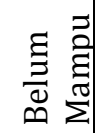 & 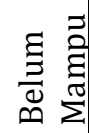 & 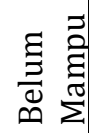 & 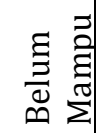 & 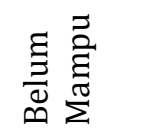 \\
\hline
\end{tabular}

Keterangan:

a. Mengenali sifat berurutan dari bilangan pecahan

b. Mengenali keteraturan pada sistem bilangan pecahan

c. Mengetahui representasi bilangan pecahan ke dalam beberapa bentuk.

d. Mempunyai intuisi untuk memperkirakan besarnya suatu bilangan pecahan

e. Memahami operasi-operasi dan efekefeknya

f. Mengenali jenis-jenis hubungannya, dan dapat menerapkan hubungan tersebut

\section{Pembahasan}

Berdasarkan hasil penelitian terlihat bahwa pada indikator pertama yaitu kefleksibelan terhadap bilangan pecahan diketahui bahwa hanya subjek pada kemampuan tinggi saja yang sudah mampu sedangkan pada kemampuan sedang dan rendah dapat dikatakan belum mampu. Pada kemampuan tinggi, subjek dapat melihat secara langsung bahwa hubungan antara bilangan yang diberikan sehingga tanpa proses perhitungan yang berlangsung lama, subjek pada kemampuan tinggi langsung bisa mengkalkulasikan proses pemecahan masalah dengan tepat. Hal ini senada dengan NCTM (2000) bahwa anak yang mempunyai number sense yang baik akan memiliki pengertian yang baik tentang makna bilangan serta mengembangkan berbagai hubungan antar bilangan. ${ }^{1}$ Berbeda dengan subjek kemampuan sedang dan rendah, dimana pemahaman terhadap suatu nilai pecahan hanya sebagai satu kesatuan, meskipun pada akhirnya dalam proses pemecahan masalahnya menggunakan langkah prosedural sesuai dengan yang sudah pernah mereka pelajari sebelumnya.

Pada indikator yang kedua dimana kepekaan terhadap operasi dan hubungan antar operasi hitung didapati bahwa subjek pada kemampuan tinggi ada yang sudah mampu dan ada belum mampu. Hal ini terlihat ketika subjek melakukan suatu taksiran pada sebuah bilangan yang menyebabkan kesalahan perhitungan. Berbeda dengan kemampuan sedang dan rendah dimana sering melakukan kesalahn ketika melihat suatu pembagi. Subjek tidak bisa merubah suatu nilai dari bilangan desimal dan penggunaan nilai desimal tersebut sehingga mengakibatkan kesalahan perhitungan. Menurut Sowder (1992), salah satu indikasi adanya kemampuan number sense pada diri seorang anak adalah memahami tentang representasi bilangan dan memiliki kemampuan untuk mengubah bilangan menjadi bentuk lain yang senilai dengan tepat dan efektif. ${ }^{8}$

Pada indikator ketiga dimana kemampuan menggunakan konsep bilangan dan operasinya dalam melakukan peritungan, didapati bahwa pada pada kemampuan tinggi, semua subjek sudah mampu melakukan perkiraan dan langkah perhitungan yang benar dengan berbagai macam cara. Hal ini sesuai yang diutarakan oleh Fosnot (2000) yaitu seseorang yang memiliki kemampuan number sense yang baik mereka dapat menentukan strategi yang tepat dan efisien dalam menyelesaikan masalah tersebut. $^{5}$ 
Disamping itu number sense membantu siswa berpikir fleksibel dan kreatif dalam menyelesaikan masalah-masalah terkait dengan perhitungan. Menurut Carlyle (2012), hal ini meningkatkan kepercayaan diri siswa mengenai bilangan dan operasinya. ${ }^{1}$ Berbeda dengan kemampuan rendah dan sedang dimana belum ada satu pun yang bisa mengerjakan dengan benar, baik dari estimasi maupun pengerjaan secara prosedural. Didapati pula bahwa soal yang menurut mereka membutuhkan perhitungan yang sangat panjang. Peserta didik yang memiliki number sense yang rendah cenderung tidak memiliki ketertarikan dalam perhitungan angka (Carlyle, 2012). ${ }^{1}$ Dalam hal ini, keterampilan number sense memerlukan keterampilan penalaran matematis yang baik tetapi juga keterampilan berpikir kreatif. Dengan proses membayangkan pikirannya, peserta didik dapat menentukan strategi yang tepat dan efisien.

\section{SIMPULAN DAN SARAN}

\section{Simpulan}

Berdasarkan penelitian yang sudah dilakukakan, didapatkan kesimpulan yaitu:

a. Kemampuan number sense mahasiswa PGMI kelompok tinggi

Dapat ditarik kesimpulan bahwa pada kelompok tinggi, mahasiswa sudah menguasai konsep dasar dari number sense meskipun terdapat sedikit kesalahan tetapi tidak terlalu mempengaruhi dari kemampuan number sense.

b. Kemampuan number sense mahasiswa PGMI kelompok sedang

Mahasiswa pada kelompok sedang belum mampu memahami dan menguasai sepenuhnya terkait konsep dasar dari number sense, hal ini terlihat ketika hampir semua indikator dari number sense belum terpenuhi.

c. Kemampuan number sense mahasiswa PGMI kelompok rendah

Sama halnya dengan kemampuan number sense mahasiswa kelompok sedang, mahasiswa pada kelompok rendah juga belum mampu memahami dan menguasai sepenuhnya terkait konsep dasar dari number sense, hal ini terlihat ketika hampir semua indikator dari number sense belum terpenuhi

\section{Saran}

a. Bagi Program Studi

Tidak bisa dipungkiri bahwa pada umumnya pendidik adalah ujung tombak dari suatu pendidikan, terutama guru madrasah ibtidaiya atau sekolah dasar pada khususnya. Diharapkan kedepannya Program Studi PGMI dapat memberikan suatu kebijakan untuk memperhatikan pentingnya kemampuan number sense mahasiswa sebagai calon pendidik terutama mahasiswa konsentrasi matematika.

b. Bagi Dosen Konsentrasi Matematika Sudah menjadi tugas dan kewajiban dosen maupun guru untuk mencerdaskan anak bangsa. Oleh karena itu, dosen konsentrasi matematika Program Studi PGMI diharapkan terus memacu semangat belajar tentang pentingnya number sense selama proses perkuliahan untuk dapat memicu dan memacu semangat dan motivasi mahasiswa konsentrasi matematika sebagai calon pendidik.

c. Bagi Mahasiswa

Stigma menakutkannya matematika pada mata pelajaran sekolah memang masing sangat sering digaungkan. Diperlukan pendidik yang mampu mengkikis stigma tersebut sampai habis. Hal ini dapat terlaksana jika peserta didik mempunyai pondasi matematika yang kuat. Untuk itu, mahasiswa PGMI selaku calon pendidik diharapkan memiliki semanat untuk mewujudkan hal tersebut, diantaranya yaitu selalu mengasah dan melatih kemampuan matematika terutama kemampuan number sense yang sangat berpengaruh dalam pembelajaran matematika di madrasah ibtidaiyah dan sekolah dasar

\section{UCAPAN TERIMA KASIH}

Kegiatan penelitian ini merupakan salah satu bagian dari Tri Dharma Perguruan Tinggi yang harus dilaksanakan oleh civitas akademika khususnya para tenaga pengajar. Peneliti mengucapkan terima kasih 
kepada UIN Mataram, Program Studi PGMI, mahasiswa PGMI selaku sebagai subjek penelitian, serta pihak-pihak yang telah meberikan konstribusi baik secara langsung maupun tidak langsung selama penelitian.

\section{REFERENSI}

[1] Carlyle, Ann, and Brenda Mercado. (2012). Teaching Preschool and Kindergarten Math: More than 175 Ideas, Lessons, and Videos for Building Foundations in Math, a Multimedia Professional Learning Resource. Sausalito, CA: Math Solutions, Print

[2] Dehaene, Stanislas dan Wilson Anna. (2007). Number sense and Developmental Dyscalculia. Cognitive Neuroimaging, INSERM-CEA Unit 562. Perancis: Service Hospitalier Frédéric Joliot

[3] Depdiknas. (2004). Kerangka Dasar Kurikulum. Jakarta.

[4] Der-ching Yao, Mao-neng, Wei-Jin, li. (2008). Development of a computerized number sense scale for 3-rd graders:reliability and validity analisis, 7, 110 - 124

[5] Fosnot, Catherine Twomey. (2001). Young Mathematics at Wosubstruction: Constructing Number Sense, Addition, and Substraction. USA

[6] National Council of Teachers of Mathematics. (2000). Principles and Standards for School Mathematics. Reston, VA: National Council of Teachers of Mathematics.

[7] National Council of Teachers Mathematics. (2000). The number sense and operation standart of the principles and standart for school mathematics includes several concepts and skills related to beginning number sense. (http://standards.nctm.org/docment/appendix/numb. $\underline{\mathrm{htm}})$

[8] Sowder, Judith T. (1992). Making Sense of Numbers in School Mathematics." In Analysis of Arithmetic for Mathematics Teaching, edited by Gaea Leinhardt, Ralph Putman, and Rosemary A. Hattrup, 1-51. Hillsdale, N.J.: Lawrence Erlbaum Associates 